\title{
O PROJETO DO NOVO CÓDIGO CIVIL \\ E A TUTELA DOS DIREITOS \\ INDIVIDUAIS E COLETIVOS
}

Jussara Suzi Assis Bonges Nasser Ferreiral

SUMARIO: A tradicano das codificaçoss. - 2. O Projeto do novo Codigo Civil brasileiro. - 3. Diretos subjetivos e as codficacoes de direitos privados. - 4. Principats inovacoes: Parte Gerale Parte Espectal. - 5. Conclusoes. - 6.Bibliografia

RESUMO:O Projeto de novo Código Civil mantem a classica divisăo em Parte Geral e Parte Especial, acrescentando novo livro para regular o Direito de Empresa.

Adotando discurso normativo progressista inova ao tutelar, de par com a matéria propria do direito privado, a geracăo dos direitos transindividuais.

PALAVRAS-CHAVE: Projeto do Código Civil, Inovaçóes, Direitos Individuais e Transindividuais

ABSTRACT: The project of the new Civil Code keeps the classic division beween the General and the Special Parts, adding a new boon to regulate the Company Law.

Using a progressive normative speech, it innovates protecting beside the own private law, the generation of the transindividual rights.

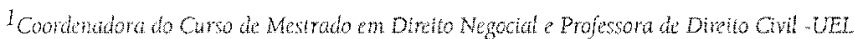




\section{A TRADIÇÃO DAS CODIFICACOÓES}

A tradição do direito guarda uma extensa e bem produzida codificação. Relatos histónicos afimmam o código de Manu, na Índia, como o mais antigo de que se tem notícia. Neste elenco cabe registrar as mais clássicas e tradicionais codificaçoes conhecidas pelas civilizaçōes pretéritas, tais como, o Código de Hamurabi (1690 a. C.); a lei das XII Tábuas; Código Gregoriano (291 d. C.); Código Hermogeniano (295 d. C.); Código Teodosiano (438 d.C.) e Código Justiniano que compöe o "corpus juris civilis" (534).

Registros mais recentes revelam as codificaçoes Afonsinas (1446) seguidas, posteriomente, pelas Manuelinas (1521).

Como marca de modernidade surgem os Código da Prússia, e Código de Napoleão (1804), como posteriormente, foi denominado o Código Civil rrancês, Conte de inspiração para outros tantos códigos que se seguiram como o Código da Austria, BGB alemão de 1896, Código Suisso de 1881 - 1907. Código Civil Brasileiro de 1916, e o Código Canônico (1917), dentre outros.

O direito civil pátrio levou, aproximadamente, um século até ser codificado. A Constituição Imperial de 1824 já recomendava a codificação daquele ramo do direito. En 1858 Augusto Teixeira de Freitas apresentava a obra Consolidação das Leis Civis, com mais de 5.000 artigos e que por razōes diversas não foi acolhida, sendo largamente utilizada por Velez Sarslield, autor do Projeto do Código Civil Argentino. Somente em 1899 foi que Clóvis Bevilaqua iniciou a redação do Projeto do Código Civil Brasileiro que restou aprovado pela Lei 3071 de 01.01.1916.

A despeito de tão nobre produção normativa codificada, manifestaçoes contundentes, contrárias aos códigos sempre se fizeram presentes, como a clássica crítica externada por Savigny, acusando os códigos de fossilizarem o direito, impedindo a sua evolução natural e imobilizando o 
espirito do jurista, pela rigidez de suas formulas. Nessa linhagem crítica entenderam Heni, León e Jean Mazeaud que o Código Civil Francês, não mais representava o estado do direito positivo francês. E finalmente, a crítica mais atual alirma pertencerem as codificaçōes ao passado, estando o modelo esgotado enquanto processo histórico, cultural e jurídico, exigindo uma superação.

Enquanto criticas ácidas são dirigidas aos códigos, vozes erguem-se em defesa, para justificar a indispensabilidade de uma construçăo normativa sistemática, única, reunindo por ordem, matérias que pela própria natureza, não devem prescindir de tratativa formulada em conjunto ordenado, na lorma de código.

Atento a críticas que tais, o relator do atual Projeto do Codigo Civil, senador Josaphat Marinho, sobreleva a preocupação com um código que elaborado para o nascer de outro século, deve traduzir-se um formulas genericas cflexiveis, em condiçoes de resistir ao embate de novas idélas, apresentando visão coletiva, para que reflita, quanto possivel, os influxos da cultura nacional. 20 relator ainda enfatiza a questão da inflação da produção normativa no país, que através da exacerbada quantificação de leis especiais, dificulta, sobremaneira, o acesso à informação enquanto meio de conhecimento juridico.

\section{O PROJETO DO NOVO CÓDIGO CIVIL}

Mantendo a estrutura tradicional dos códigos e o apego ao de 1916. o Projeto esta dividido em Parte Geral e Parte Especial.

A Parte Geral apresenta-se tripartida em tres livros: das pessoas, dos bens, dos fatos jurídicos. A Parte Especial vem estruturada em cinco livros a saber: do direito das obrigacoes, do direito de empresa, do direito das coisas,

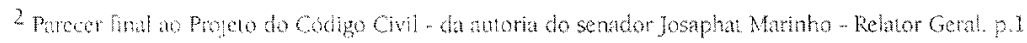


do direito da família, do direito das sucessöes.

Nesta fase, a grande novidade, reside no acréscimo do livro sobre o direito de empresa, inexistente no atual código. As disposiçöes finais e transitórias, em livro complementar, concluem o Projeto distribuido, inicialmente, em um total de 2073 artigos, que no parecer preliminar do relator são marcados por normas de sentido genérico ou de alcance social, obedientes a uma sistematização, sem rigidez incompativel com a realidade. Sem pretensäo de promover a unidade do direito privado. ${ }^{3}$

Da Parte Geral, que the coube redigir, assinala o ministro Moreira Alves, que na atualizaça dos principios do Código Civil em vigor, se ateve à doutrina mais moderna em que ela já se encontra assente, e se ajusta a necessidades práticas a que visa uma codificaçăo. ${ }^{4}$

De fato, ainda que de um räpido e primeiro exame do Projeto percebese, com facilidade, a preocupação com a natureza genérica das nomas e seu alto alcance social.

A atualização de seu conteúdo é outro ponto que merece relevo, considerando os 20 anos de tramitaça. Notadamente, no campo do direito de Eamilia estão concentradas as harmonizações com os dispositivos da Carta Magna de 1988. Os avanços tecnológicos e as possiveis manipulações genéticas conduzem o legislador a reafirmar, ainda mais o princípio da indisponibilidade do estado das pessoas, recepcionando, porém sem interferir, as legislaçoes especiais, precedentes.

A prudencia e a flexiblidade são, em verdade, autênticos princípios que norteiam o legislador, com frequência constante, fazendo-o ponderar se o codigo atual, provindo do saber e da experiência de Clovis Bevilaqua, e em vigor desde 1917, sofre a incidencia de múltiplas leis, que o modificaram ou criaram sistema normativo parcialmente diverso, jâ agora, $\varepsilon$ methor tentar a inovaça global do que o manter mutilado, e por isso mesmo de complicada interpretacaao, em prejuizo da sociedade $e$ da ordem juridica. ${ }^{5}$

\footnotetext{
3 which, iden, $;, 10$

4 Ibiden, dem, p. 10

5 Tbtam, idem, 9.7
} 
De fato o atual Código Civil vem de há muito retaliado por uma inlinidade de leis esparças, levando em conta de que, a harmonização em relação à Constituição Federal e, referida anteriormente, é de todo indispensável. Aqueles que propugnam pela superação dos modelos codificados, não apontam, contudo, alternativas vantajosas, modernas e mais adequadas que possam substituir, com excepcional beneficio, o tradicionalismo dos códigos.

Diante da prudência do legislador pátrio que, insistentemente, tem recomendado um trabalho legislativo pautado pela isenção do dogmatismo antes aberto a imprimir dareza, seguranga e fexibilidade do sistema em construcão, c portanto adequada a recolher e regular mudanças e criaçóes supervenientes, a inclinaça da articulista, nesta hora, é de considerar a presente codilicação benéfica, que vem para modificar, atualizar, hamonizar, impondo-se útil e necessária, arredando a preocupação com o hermetismo das codificaçoes que em verdade nâo reside na forma e antes no conteủdo que se possa conceber àquela. É de se admitir, parecer prematuro qualquer posicionamento delinitivo a lavor ou contra o Projeto, tratando-se de fase preliminar de estudos. Entretanto, a postura franca e aberta que tem inspirado os membros integrantes da Comissão Especial, capitaneados pelo relator geral senador Josaphat Marinho, conduz à reflexão de que se não há caminho novo, ao menos haverá um jeito novo de caminhar, como poeticamente nos tem orientado Thiago de Melo

\section{DIREITOS SUBJETIVOS E CODIFICAÇÕES DE DIREITOS PRIVADOS}

Fin sede de diretio subjetivo, indispensavel a retomada histórica de origem romanistica que plasmou o conceito de facultas agendi. Contudo, a evolução da melhor doutrina retoma a análise conceitual do direito subjetivo sob uma pluralidade ótica que perspassa por teorias que concebem o direito

6 lbiden, idom. p.7 
subjetivo ora como poder (Pokan), ora como mero reflexo do direito subjetivo (Kelsen), outras vezes como situação subjetiva (Reale) ou como palavra oca para descrever uma situação (Olivecrona).

Estas brevissimas digressoes acerca do locus conceitual do direito subjetivo são trazidas à colação, apenas com o intuito de focá-lo em relação à natureza dos direitos previstos no Código Civil, eminentemente, destinado à tutela dos direitos privados, até então.

Sabidamente os direitos subjetivos estão bipartidos em públicos e privados. Entrementes a concepçäo publicista de direitos que tais, esbarrou em forte resistência, somente passando a ser aceita a partir da teoria jellinekiana que afirmou e demonstrou a existência dos direitos subjetivos públicos, divididos em direitos de: liberdades de ação, de petição e direitos políticos.

Tangentemente aos direitos subjetivos privados, concebidos como aqueles em que a obrigação deve ser cumprida por pessoa de direito privado, expressou a univocidade conceitual dos tratadistas clássicos da matéria.

Os direitos subjetivos privados, estäo bipartidos em patrimoniais e não patrimoniais. São direitos subjetivos patrimoniais, os direitos reais obrigacionais, sucessórios, intelectuais e pela dição do futuro Código Civil, de ser levado em conta, o direito de empresa. O direito de família, e os personalíssimos, pela própria conformação, compōem o rol dos direitos não patrimoniais.

Esta era a posição clássica que até então albergava a tratativa dos direitos subjetivos, concebido sob a ótica de um estado de direito sim, porém liberal e pouco intervencionista.

A doutrina pátria, bem como os tribunais, sempre conceberam os direitos subjetivos, realizando uma leitura impregnada sob ótica deste tipo de organização estatal, altamente protetiva dos direitos individuais.

As mudanças verificadas no contexto político mundial, modernizando a estrutura estatal tornando-a concentânea com as exigências da sociedade, que encontra-se no atrium de uma nova era, força o Estado a proceder uma revisão estrutural, envolvendo valores das mais variadas matizes, para 
alcançar as mudanças almejadas pelos individuos e definir-se como estado social de direito. Este avanço produz efeitos diretos na tutela dos direitos, até então priorizados em sua categoria individual, para trazer uma transfulgaz evolução em favor da tutela dos direitos coletivos, difusos e individuais homogêneos, até então preteridos. Este grupo de direitos e sua respectiva proteção destacou-se, presentemente, no ordenamento jundico, com indizivel significaçăo e importância, pelo vastíssimo campo de tutelas que se pöem em favor da comunidade. Assim, via de consequência, toda a concepcão de direito subjetivo, amalgamada pelo estado de direito liberal, vivência fase reflexiva, altamente, benéfica, impulsionada pela perspectiva social, assumida pelo estado de direito no limiar de um novo tempo, marcado pela globalização, onde não há que se falar em sujeito de direito, encastelado no contexto individualista de então, até porque vivenciase um direito planetário, onde a evolução tecnológica, a celeridade dos meios de comunicação, as comunidades estatais em suas expressōes socioeconomico-juridicas, priorizam os interesses coletivos, como marca de qualidade do social, para o terceiro milenio.

\section{PRINCIPAIS INOVAÇÕES: PARTE GERAL E PARTE ESPECIAL}

\subsection{A Tutela dos Novos Direitos Transindividuais}

As transformações sociais, as grandes conquistas no campo das biotecnologias, de par com os avanços das ciências em geral, o refinamento do estado social de direito oportunizaram o surgimento de uma gama considerável de novos direitos. Para lins deste estudo interessa, sobremaneira, o enfrentamento dos direitos transindividuais que despontaram no ondenamento furídico pátrio, com a adoção da ação civil pública - lei 7.347/85, relerida na Constituição Federal no artigo 129 , inciso III, seguida do Código de Defesa do Consumidor - Lei $8.078 / 90$ e por fim, o Projeto do Código Civil, laz menção expressa aos direitos supra individuais ao consagrar o novo direito de empresa, e também ao redefinir o conceito de propriedade, dentre outros pontos. 
Antes mesmo do enfrentamento das inovaçôes em matéria civil, cabe registrar, como grande avanço, a tutela dedicada aos direitos transindividuais, com acima referidos.

Neste contexto adequadíssima a lição sempre erudita de Noberto Bobbio quando redimensiona as geraçōes de direitos, fixando-as em cinco grupos:

1)geraçăo dos direitos individuais, que pressupōem a igualdade formal perante a lei considerando o sujeito abstratamente. Tal como assinala Bobbio, esses direitos possuem um significado filosófico-histórico da inversão, característica da formaçăo do Estado moderno, ocorrido na relação entre Estado e cidadãos: passou da prioridade dos deveres dos súditos à prioridade dos direitos do cidadão, emergindo um modo diferente de encarar a relaçăo politica, não mais predominamente do ângulo do soberano, e sim daquele do cidadão, em correspondencia com a afirmação da teria individualista da sociedade em contraposiçāo à concepção organicista tradicional.

2)geraça dos direitos sociais, nos quais o sujeito de direito é visto enquanto insericlo no contexto social, ou seja analisado em uma situação concreta. Trata-se da passagem das liberdades negativas, de religiano e opiniāo, por exemplo, para os direitos políticos e sociais, que requerem una intervençāo direta do Estado.

3)geraçăo dos direitos transindividuais, também chamados direitos coletivos e dilusos e que, no geral compreendem os direitos do consumidor e os direitos relacionados a proteção do meio-ambiente, respectivamente.

4) ģcraçäo dos direitos de manipulaçăo genética, relacionados à biotecnologia e bioengenharia, e que tratam de questöes sobre a vida e a morte, sobre cópia de seres humanos, e que requerem uma discussäo ética prévia.

5)geração dos direitos da realidade virtual, que nascem do grande desenvolvimento da cibernética na atualidade, implicando no rompimento das fronteiras traclicionais, estabelecendo conflitos entre paises com realidade distintas, via Internet, por exemplo. ${ }^{7}$

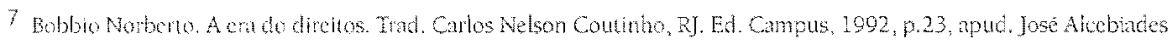

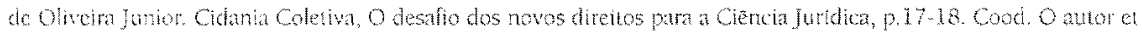
all, Flotanopolis. Exi. Fralelo 27, 1996. 
Os códigos säo conjuntos de normas estabelecidos por lei. O que caracteriza o código é a regulaģo unitánia de um ramo do direito. ${ }^{8}$

O Projeto do Código Civil revela um novo conceito de codificação, realizando feito raro, de regular direitos de geraçóes diversas, como os enumerados por Bobbio. O Projeto trata dos direitos individuais - como marca própria de uma legislação voltada para a tutela de direitos privados. Mas vai além ao dispor ainda sobre os direitos sociais, transindividuais, direitos de manipulação genética e finalmente os direitos da realidade virtual.

Outra grande característica dos códigos está em sistematizar grandes campos conceituais do conhecimento jurídico, porém reservado a codificação a um campo exclusivo do direito, marcados pela rigidez e via de regra, pelo conservadorismo.

O Projeto do Código Civil, desde logo, aponta para inovações estruturais ao elaborar discurso normativo marcado pela interdisciplinaridade, notadamente, visivel no livro reservado ao direito de empresa e no livro dos direitos reais.

A abordagem do direito de empresa reúne conceitos do direito civil, bem como do direito comercial e linalmente do próprio direito empresarial. De outra parte, ao inovar, radicalmente, o conceito função da propriedade, o novo Código Civil importa conceitos lapidares do direito ambiental, do código llorestal, por exemplo.

Constata-se das abordagens interdisciplinares a tutela dos direitos coletivos e difusos, finalmente codificados em seara de direito material. É certo registrar que os novos direitos interindividuais, ainda em lase de aperfeiçoamento, tem recebido um impulso notável, mas em sede de direito processual, O direito material, deles tem se ocupado, porém timidamente, através de legislação esparça a exemplo da Lei $6.938 / 81$ que dispōe sobre a política nacional de meio ambiente e ao estabelecer seus objetivos e

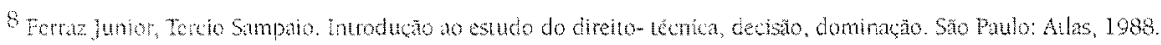
1. 214 
principios, em circulo estreito, propõe, singelamente, um direito material ambiental.

O parecer final do Projeto destaca no direito de empresa, artigo 1.129 e 1.130 ser regra essencial, quanto á sociedade dependente de autorizaçăo, a que faculta to podor executivo negar permissäo, se a sociedade näo atender às condiçoes economicas, financeiras ou juridicas especificadas em lei, ou quando sua Criaça contrariar os interesses da economia nacional. E complementa: de relevo, por igual, ca disposiça que faculta ao poder executivo exigir que se procedam a alteracáo ou adiamento en contrato ou estatuto de sociedade, como afirmação de estado em defesa da ordem juridica ou do interesse coletivo.

A ênfase à tutela do interesse coletivo eleva aquela proteçăo, até então contida no âmbito processual, definitivamente, para o campo material. O conceito de interesse coletivo esta a indicar a justa regulaçăo daquele campo de interesses que agora referem a um grupo, a uma comumidade e não apenas e tào somente ao individuo. Estão, finalmente, contemplados os interesses sociais, o interesse público, descritos em autentica norma de direito metaindividual.

Outra não foi a dicção adotada pelo artigo 1.229 do Projeto que não mais concebe a propriedade naquele rígido estreitismo conceitual clássico e ultrapassado, como o direito de usar, gozar e dispor de seus bens.

Apesar de mencionar esses descritores, pois que caracteres da propriedade acrescenta, expressamente a previsão da função social e ambiental da propriedade e que em verdade vêm para por cobro às clássicas situações pertinentes ao uso, gozo e abuso da propriedade.

Em boa técnica legislativa o direito de propriedade vem estabelecido como aquele que deve ser exercido em consonância com as suas finalidades econômicas e sociais e de modo que sejam preservados, de conformidade com o estabelecido em lei especial, a flora, a fauna, as belezas naturais, o equilíbrio ecológico e o patrimônio histórico e artístico, bem como evitada a poluição do ar e das águas (art. 129 \& único). Arremata o parecer final, afirmando que explicitamente, portanto, condiciona a conveniência privada ao interesse coletivo.(sem grifo) 
Esta, sem dúvida e uma conquista cerebrina. A codificação civil acolhe a legislaçäo especial, em favor da proteção dos direitos coletivos e difusos, deixando as tribunas douradas das sistematizaçóes univocas, para agasalhar imperativos maiores, voejando em círculos estreitos inova, brilhantemente, trazendo a marca do novo, imprescidivel à justa regulação, em favor da incomensurável grandeza, traduzida na tutela dos novos direitos metaindividuais. O Projeto do Código Civil, pode, já por esta razão, ser considerado uma codificação de elevação do direito.

\subsection{Das Inovações da Parte Geral}

Considerando ser este o primeiro contato da articulista com a recente revisão do Projeto do Código Civil, constitui proposta para o momento, uma incursão, mais para notíciar as inovaçoes do que, propriamente, enfrentá-las analiticamente.

Assim, a critério nosso, são indicados alguns dos novos dispositivos, considerando as limitaçoes naturais, de abordagens dessa natureza.

0 artigo $1^{\circ}$ do Projeto substituiu a denominaçäo todo homem por todo ser humano, que em verdade, pelo significado mais abrangente esta a referir com maior grau de adequaçăo o indivíduo, enquanto sujeito de direito.

A maioridade foi reduzida para dezoito anos.

Os direitos de personalidade são contemplados com proteção mais ampla e elicaz expressada de forma categórica e agora por disposiçăo legal como intransmissiveis e irrenunciáveis, não podendo seu exercicio sofrer limitaçōes voluntárias. Em bom tempo o legislador, nesse passo, incorporou o que de há muito doutrina e jurisprudência haviam consagrado.

No artigo 12 estäo elencados as garantias do uso de medidas que façam cessar a ameaça, ou a lesão a direito de personalidade, prevendo perdas e danos.

O artigo 13 também importa conceitos, desta feita da bioética, do biodireito e das legislaçôes especiais sobre transplante de órgãos e tecidos 
com fins terapêuticos ao proibir no art. 13 os atos de disposiçóes do próprio corpo, quando implicarem diminuição permanente da integridade física, ou contrariarem os bons costumes, salvo por exigência médica.

O artigo em questão faz por merecer, em outra oportunidade, quiçá, interpretação face a novíssima permissão para que se proceder a adaptação de sexo do transexual, com a ablação de órgãos genitais masculinos ou reconstruçăo de tais órgãos em pacientes do sexo feminino, passando ainda por uma leitura em relaçăo ao direito à intimidade e à honra.

A disposiçāo gratuita do próprio corpo, no toda ou em parte, para depois da morte, com objetivo científico, ou altruísta esta prevista no art. 14, buscando harmonizar os dispositivos da recente lei $n^{\circ} 9.434 / 97$, que determinou, em verdade, a doação compulsória, do próprio corpo no todo ou em parte após a morte. Bem pela forma e não pelo conteúdo, impregnado de nobreza, sofre aquela legislação criticas candentes que chegam mesmo a fulminála sob o argumento de inconstitucionalidade. Se, porventura, prosperarem teses que tais, as doaçōes pós mortem, do corpo humano, estarão asseguradas pela correta forma adotada pelo Projeto.

Grande avanço esta reservado, na Parte Geral aos atos e negócios juridicos que, finalmente são tratados como figuras distintas e define o ato jurídico lícito e ilícito. O Projeto talvez inspirado na boa técnica germânica deverá conceituar o ato jurídico como aquele que produz todos os seus efeitos, conforme previstos em lei. Já o negócio juridico, além de produzir os efeitos previstos em lei, terá ao talante das partes, espaço reservado para que os ajustes de interesses possam produzir efeitos para além dos limitados em lei, obviamente respeitados os requisitos essenciais de validade do negócio juridico, como de há muito preleciona a teoria geral do negócio jurídico, como delendida pela escola germânica, por Emilio Betti e Pontes de Miranda, dentre outros.

A omissão do Código Civil atual, no que diz respeito ao conceito de lesão loi suprimida, retirando-a daquela faixa nebulosa, para conceituá-la no art. $157 \& 1^{\circ}$ como sendo aquela ocomida sob premente necessidade, ou por inexperiencia, devendo ser apreciada a desproporção das prestaçoes sugerindo os 
valores vigentes do tempo em que foi celebrado o negócio juridico.

Uma vez mais, o Projeto brindou a construça doutrinária e jurisprudencial em favor do conceito de lesão de direito, consagrado naquelas esleras.

A mença expressa a reparabilidade do dano moral esta contida no artigo 186 , e de conformidade com a previsão constitucional do art. $5^{\circ}$, incisos $\mathrm{V} e \mathrm{X}$.

A desconsideraçäo da personalidade juridica impóem-se sempre que representar impedimento ou obstáculo à reaparabilidade dos prejuizos solrido pela parte. Cabe refletir, neste particular, já considerando o novissimo conceito de função social e ambiental da propriedade, sobre os beneficios que este instituto poderá proporcionar, referentemente a empresas, altamente poluidoras do meio ambiente e que nada ou quase nada reparam, ficando seus representantes, no mais das vezes, em suas fortunas amoedadas, intocaveis, por faltar ao ordenamento noma, de calibre eficaz, como bem tem demonstrado ser, a desconsideracão da personalidade jurídica em sede do Código de Defesa do Consumidor.

\subsection{DAS INOVAÇÕES DA PARTE ESPECIAL}

\subsubsection{Do Direito das Obrigaçōes}

No âmbito dos Direitos das Obrigaçóes percebe-se com nitidez, a permanente preocupação do legislador em manter o equilíbrio do discurso normativo, de conformidade com a nota relevante em favor do social, expungindo de vez, o exclusivismo das tutelas de interesses individuais.

Nessa esteira, resta reconfimada a liberdade de contratar, contudo jungida aos limites e função social do contrato, de conformidade com a regra contida no artigo 421, sendo que o Projeto repele o individualismo condenável na expressão cristalina do relator geral Josaphat Marinho.

E evidente que o contexto essencialmente privado e partatio ocupa hoje parcela muito pequena do mundo negocial, embora nâo tenha desaparecido. É contrato de quem adquire o automóvel usado, etc... como se pode perceber, a atual 
dinämica social relega a plano secundario esse contrato. Cada vez mais raramente se contrata com uma pessoa fisica. A pessoa juridica, a empresa, os grandes detentores do capital, enfim, e o próprio estado sāo os que fornecem os bens $e$ serviços para o consumidor final. Os contratos săo negócios de massa. ${ }^{9}$

Bem por reconhecer a explosão dos contratos de massa os contratos de adesão vềm regrados pelo Projeto (artigos 423 a 424) protegendo o contratante aderente em relação às cláusulas ambíguas ou contraditórias, proibindo a renúncia antecipada a direito resultante da natureza do negócio, a exemplo dos delineamentos, a este respeito, regrados pelo Código do Consumidor.

artigo 425 recepciona os contratos atípicos, ressalvando a observăncia às normas gerais fixadas no Código, isto porque a importancia principal em qualificar como lípica ou atipica está na sua integraçäo e intepretaça 10 e que ora em diante deverá atender de pronto, todas as normas gerais previstas pelo legislador e que em verdade principiam por tecer uma grande e nova teoria geral do contratos.

Una vez mais, a exemplo da legislação reguladora das relaçöes de consumo, adotou o legislador civilista, a teoria da imprevisão, expressada pela cláusula rebus sic stantibus (art.478) autorizando a resolução dos contratos de execução continuada ou diferida, se a prestação de uma das partes se tomar excessivamente onerosa, com extrema vantagem para a outra, en virtude de acontecimentos extraordinários e imprevisiveis.

Nesse diapasăo do Projeto justifica que cautelosamente pois, reduz a majestade do contrato, substituindo a velha clausula pacta sunt servanda, dos códigos individualistas, pela nova regra. Evidentemente, o primado dos direitos individuais, inicia por ceder espaço, como imperativo de grande relevo, que permeia todos os livros do futuro Código Civil, para elevação do ordenamento juridico nacional.

Em favor da teoria da imprevisăo, as mais expressivas defesas säo representadas pela melhor doutrina expressa nas contribuições inestimáveis

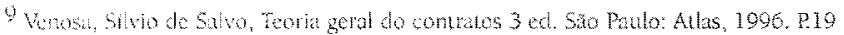
10 Lbidem, idem $p .51$
} 
de Windscheid (a pressuposiçăo), Lorenz (os fatores objetivos e subjetivos, Medeiros da Fonseca (a equidade e a justiça), Covielo ( e o estado de necessidade). Dentre os juristas que enfrentam a imprevisão contextualizada através do vínculo social ou em fundamentos juridicos afins, vale destacar Mantiga, Betti e por derradeiro, Hauriou (tendências limitativas) e Cossio (tansformaço do ato em fato jurídico). A temática vem, brilhantemente, esgotada por Nelson Borges ${ }^{11}$ em sua dissertação de mestrado, estudo ímpar que em uma das conclusões afirma: no principio rebus sic stantibus se encontra muito mais vida e dinamismo do que na regra pacta sunt servanda. Esta, por ser uma necessidade à segurança e estabilidade das partes - da qual nunca se discordou - acabou por se transformar em dogma estatico que desconsiderou o fato de que o direito é vida e, vida $e$, acima de tudo, movimento, transformaçăo. Este aspecto é da essência do principio rebus sic stantibus.

O princípio sob análise vem complementado pela vedação do enriquecimento sem justa causa, seguido da obrigação de restituir o que indefinidamente possa ter sido auferido.

Com a adoção do princípio rebus sic stantibus pelo Projeto, prontamente surge o questionamento se tal principio passaria a alcançar legislação esparça, como por exemplo do inquilinato que, prevê revisão contratual própria. Na interpretaça da maioria dos tribunais pátrios, aqueles contratos nảo estão sujeitos ao princípio, como disposto no Código do Consumidor, por não versar a locação sobre relação do consumo ou serviço. Entretanto, considerando a natureza genérica da norma codificada, tudo indica que a teoria da imprevisăo, poderá ser invocada em favor de todos os contratos de execução continuada ou diferida, atingidos por desequilibrio imprevisivel.

O novo livro sobre Direito de Empresa traz, para a codificacão, a marca indelével do novo, sugerindo mesmo uma fusão do direito civil e do direito comercial em favor do direito empresarial, mais modemo e abrangente que o clássico direito comercial, ao tratar do conceito de empresário, empresa, sociedade, formação de sociedade, conceito de

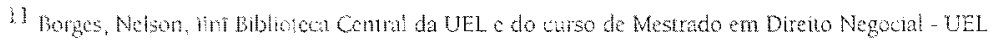


estabelecimento, tratamento diferenciado para o empresário rural e pequeno empresário e enfatizando que as normas do direito de empresa deverão ser interpretados de acordo com a diversificaçâo da atividade negocial, as condiçóes conomicas e os costumes do meio.

A nova tipificação computadorizada dos títulos de crédito ainda permanece sob forma de emenda.

O Projeto, ao condensar matéria que tal, em verdade, busca inspiraça, talvez no Código Civil Italiano que desde 1942 come affermazione di nodemi principi sociali ed economici, accanto alla proprieta, si considera essenziale il lavoro: e nel libro del lavoro troviamo la disciplina dellimpresa, che viene ad assorbire una buona parte della materia gia regolata dal codice di commercio ${ }^{12}$

No Direito das Coisas o ponto nobre foi arrebatado, às inteiras, pela modemissima dimensão conceitual que alcançou a propriedade, como comentado.

O nsucapião passa por uma redução de prazo de : vinte para quinze anos nas hipóteses de posse sem interrupção nem oposição; dez anos para quem possuir o imóvel continua e incontestadamente, com justo título e boa le. O prazo poderá, nesta última hipótese ser reduzido para cinco anos se preenchidos os requisitos de aquisição onerosa, estabelecimento de moradia ou investimentos de interesses social e economico (artigos 1239 a 1242).

0 condomínio continua com tratativa geral, seguido de normas próprias para o condomínio edilício (artigos 1314 a 1357). De igual forma o direito de superficie recebe abordagem genérica (artigos 1368 a 13750 ) e com a supedâneo de alentados estudos da lavra do ilustre jurista Ricardo César Pereira Lira, "que ressalta a importância de uma política de racionalizaçăo da utilizaça do solo urbano e de contenção do homem do campo".

A enfiteuse será extinta pela nova dicção do Projeto, mas convenientemente, sem lesar direito adquirido consoante o código em vigor.

Na esfera do Direito de Familia foram pinçadas as seguintes inovações:

- o divórcio passa a integrar as causas terminativas da sociedade

12 Trabuethi, Ahere. Inuconi di dirito wwie, $25 \mathrm{~m}$ ed. Cedam-Padova, 1981. P323. 
conjugal (artigo 1574); - o regime de comunhāo parcial de bens será o legal, na inexistência ou nulidade de convenção (artigol668); -a direção da sociedade conjugal competirá ao homem e à mulher (artigo 1569); -institui o regime de participação final nos aquestos (artigo 1700), acrescentando que cada cônjuge possui patrimônio próprio e dessa forma facilita que ambos tenham atividades autônomas.; -as dividas de um dos cônjuges, quando superiores à sua meação, não obrigam ao outro, ou a seus herdeiros (artigo 1714); -o regime de alimentos ê amplo entre parentes, conjuges, pais e filhos.

Pode ser observado que o livio reservado ao Direito de Familia caminhou por cluas grandes veredas, largamente vincadas pelo Projeto que, ora harmoniza seus dispositivos com a Constituição Federal de 1988, ora acolhe as conquistas consagradas pela jurisprudencia e doutrina.

Pontos polêmicos próprios do Direito de Família ainda repousam dentre as quase quinhentas emendas remetidas à Câmara do Deputados como por exemplo, a união estável13, seus critérios de validade, a união estável putativa, patrinòmio formado pelos conviventes e alienado por um deles em prejuizo da entidade familiar ${ }^{14}$ inseminação artificial e doação de óvulos, doação de ambriões, direitos hereditários dos embrióes fecundados in vitro, as mäes de substituição, as procriaçōes artificiais. ${ }^{5}$ a paternidade socioeletiva, a paternidade alimentar, o consentimento do marido e a assunção da paternidadel6 matérias aliás versadas fortemente, com o zelo e dedicação habituais de Rodrigo da Cunha Pereira, Eduardo de Oliveira Leite e Luiz Edson Fachin, ( jurista convidado pela Comissão Especial que contribuiu, nesta fase de revisão do Projeto).

No livro do Direito das Sucessões merecem registro:

-a redução das formalidades testamentárias; -os testamentos especiais

\footnotetext{
13 Fortem, Jusina Stat Assis Dorges Wasser. Casamento por comportamento, Rio de Janelro: Forense, 1990.

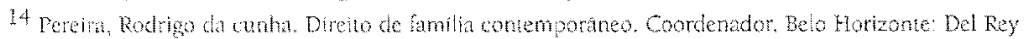

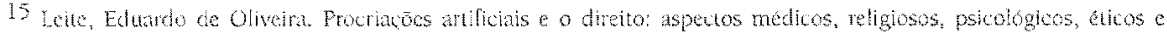
jurdicos. Sto Patwo Edicora Revista dos Thunas, 199.

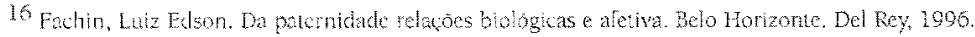


feitos a bordo de aeronaves militares ou comerciais; -mantem a ressalva à legitima dos herdeiros que não pode ser objeto de testamento.; -restringe o poder de testar estabelecendo que salvo se houver justa causa, não pode o testador estabelecer cláusulas de inalienabilidade ou impenhorabilidade quanto à legitima (artigo 1875)

Se em livros anteriores o Projeto definiu-se, como progressista, quando da tratativa de certas matérias, o mesmo, lamentavelmente, não se verifica no Direito de Família e Sucessōes.

Por derradeiro, as normas finais e transitórias que integram o livro complementar estão dirigidas à supressão de artigos inconciliáveis face à Carta Magna de 1988.

\section{CONCIUSÔES}

A harmonização buscada pelo Projeto em relação ao discurso normativo do constituiente de 1988 representa preocupação permanente „, constatada ao longo da Parte Geral e da Parte Especial do futuro Código.

Expressivas omissões do legislador são sanadas pelo Projeto, principalmente, aquelas referentes aos conceitos de ato lícito, ato ilícito, lesão, negocio juridico e reparação do dano moral.

o selo de modernidade, asseguratório do discurso progressista adotado pelo Projeto esta contido, na intençăo de restaurar o equilíbrio das correntes rompidas pelo secionamento sofrido pelo atual Código, ao longo do tempo, e para tanto, utilizando o conjunto de riquezas culturais geradas pela experiência social e juridica. As maiores expressōes de modernidade do Projeto são reveladas pela adoção de um discurso interdisciplinar contemplando: a tutela material dos direitos difusos e interesses coletivos, a desconsideração da personalidade jurídica, a redimensão do conceito e funçāo da propriedade, a adoção da teoria da imprevisão, a inclusão do novo livro sobre Direito de Empresa e a nova tipificação computadorizada dos títulos de crédito.

No a mbito do Direito de Familia, estão o maior número de dispositivos que receberam, finalmente, a conformaça em relação as previsões constitucionais de 1998. Exatamente, neste campo, foram observadas as 
tímidas contribuiçōes em estreito beneficio para um Direito de Família contemporăneo, voltado para acolher os anseios e realidades sociais, os quais o direito não pode mais ignorar.

O campo do Direitos Sucessórios restou caracterizado pela desburochatização e limitaçōes à vontade do testador, deixando a desejar enfrentamentos mais vigorosos, como indicados no capítulo anterior.

Por fim, a revogabilidade das normas será amplamente invocada, ou em razăo de já esta consagrada, ou pelo desuso de alguns institutos e por fim, objetivando minimizar, ao máximo, o conflito de normas.

\section{BIBLIOGRAFIA}

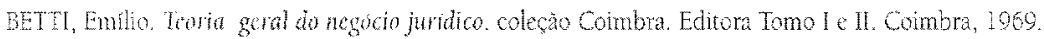

Dono, Norbert, A era do dreito. Trad. Carlos Nelson Courtinho, R. Ed. Campus, 1992, p.23 apud José Aceludus de Olivern Junion Cidadania Coletiva, o desafio dos novos direitos para a ciência juridica, p.17. 18. Comm O antor et alli, Mormopolis. Ed. Patalo 27, 1996

BORGES, Nebun. "in" Biblioten Cental da UEL e do Curso de Mestrado em Direito Negocial/UEL

DiNU, Mana lletena Lei de introduçắ no Código Civil brasileiro interpretada São Palo. Editom Sariva, 1996. FACUIN, 1.uz Thson, Da paternidade relaçes biológicas e afetivas. Belo Horizonte. Del Rey 1096.

FERRAZ JUNOR, Terón Sampato. Introduç̃o ao estudo do direito - técnico, decisano, dominação. Săo paulo: Alas 1988 . P. 214

FERlaz, Sergo. Manipulaços biológicas e principios constitucionais: uma introduça. Fonto Alcgre: Sergio Antonio Tabris Fdior, 1991

FERREIRA, Jussm Suzi Assis Boryes Nasser. Casamento por comporamento. Rio de Janeiro Forense, 1990 FRANCA, R, limengt. Principios gerais de direito. Sto Paulo: Editon Revista do Tribunais, $19 \% 1$.

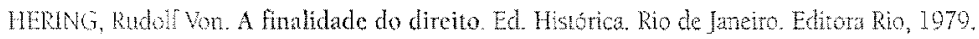

LETE, liduardo de Oliweira. Procriaçes artificiais e o direito: aspectos médicos, religiosos, psicológicos, éticos e juridicos. S5o Palo Fdtora Revista dos Tribunas, 1995

MARINHO, Japhitl. Parecer Linal ao Projeto Código Civil. Diáno do Senado Federal, Brasilu, 27 de novembro

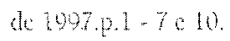

MIRANDA, Pones. Tratado de direito privado. Parte Geral 47 ed. Süo Rulo, Editora Revista dos Thbunais, 1983. NUNES, i.uz Antonio Rizzat 10 o código de defesa do consumidor e sua imerptetaça jurisprudencial.

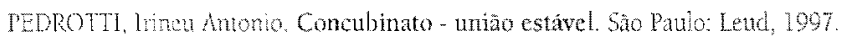

PERERA, Rudrgo de Cunha Direito de familia contemporaneo. Cootchendor Belo Horzonte: Del Rey, 1997. ROS All Sobre el derecho y la justicia Bucnos Aires: Edatonal Universitaria, 1904.

TRADUcCH, Aberto. Institucioni di dirtto civile, $25^{\text {a }}$ ed. Cedam - Patowa, 1981, p.323

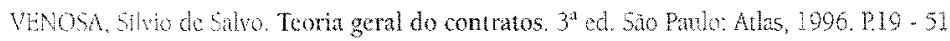

